\title{
EVALUASI PROGRAM SEKOLAH ADIWIYATA DI SEKOLAH DASAR MUHAMMADIYAH BANTUL KOTA
}

\author{
Anindya Chasti Pelita \\ Hendro Widodo* \\ Pendidikan Guru Sekolah Dasar, Fakultas Keguruan dan Ilmu Pendidikan, Universitas Ahmad Dahlan \\ Jl. Ringroad Selatan, Bantul, Daerah Istimewa Yogyakarta, Indonesia \\ *E-mail: hendro.widodo@pgsd.uad.ac.id
}

Artikel diterima: 3 September 2020; disetujui: 30 November 2020

\begin{abstract}
This study aims to evaluate and describe the supporting and inhibiting factors in the implementation of the Adiwiyata program at Muhammadiyah Bantul City Elementary School. This type of research is evaluative research with the CIPP model. Collecting data through observation, documentation, and interviews. The results showed that the context component contained environmental protection and management efforts, the input component included the budget used, the process component including the maintenance of facilities and infrastructure needed to be improved, and the product component showed that there were quite a several academic and non-academic products produced. The supporting factors for the implementation of the Adiwiyata program are supporting human resources and infrastructure, while the inhibiting factor is the lack of environmental sensitivity and knowledge of the school community.
\end{abstract}

Keywords: program evaluation; Adiwiyata program; CIPP models

\begin{abstract}
Abstrak: Penelitian ini bertujuan untuk mengevaluasi dan mendeskripsikan faktor pendukung dan penghambat dalam pelaksanaan program Adiwiyata di Sekolah Dasar Muhammadiyah Bantul Kota. Jenis penelitian ini penelitian evaluatif model CIPP. Pengumpulan data melalui observasi, dokumentasi, dan wawancara. Hasil penelitian menunjukkan komponen context memuat upaya perlindungan dan pengelolaan lingkungan hidup, komponen input mencakup anggaran yang digunakan, komponen process mencakup pemeliharaan sarana dan prasarana perlu ditingkatan, serta komponen product menunjukkan cukup banyak produk yang dihasilkan akademik dan non-akademik. Faktor pendukung pelaksanaan program Adiwiyata adalah dukungan sumber daya manusia dan sarana prasarana, sedangkan faktor penghambat adalah kurangnya kepekaan dan pengetahuan lingkungan hidup dari warga sekolah.
\end{abstract}

Kata kunci: evaluasi program; program Adiwiyata; model CIPP

\section{PENDAHULUAN}

Manusia adalah salah satu komponen yang bergantung dan mempengaruhi lingkungan hidup baik secara langsung atau kelompok yang menentukan kualitas lingkungan hidup. Perilaku manusia adalah faktor utama yang menyebabkan kerusakan lingkungan secara global. Hal ini disebabkan oleh perilaku peduli lingkungan masih sangat minim, khususnya di Indonesia. Salah 
satu upaya yang dilakukan pemerintah Indonesia untuk meningkatkan perilaku kepedulian lingkungan, yaitu dengan mengadakan Pendidikan Lingkungan Hidup (PLH) di dalam dunia pendidikan. Pendidikan lingkungan sudah pantasnya dikembangkan, hal tersebut mengacu pada kesepakatan bersama antara Menteri Lingkungan Hidup dengan Menteri Pendidikan Nasional No.07/MENLH/06/2005 dan No.05/VI/ke/2005 tanggal 3 Juni 2005. Oleh karena itu, pendidikan lingkungan hidup perlu diberikan sedini mungkin, mulai dari TK, SD, SMP dan SMA/K. Hal ini menjelaskan juga Keputusan Kementerian Lingkungan Hidup (KLH) pada tahun 1996 disepakati kerjasama pertama dengan Departemen Pendidikan Nasional, yang diperbaharui pada tahun 2005 dan tahun 2010 (Tim Penulis, 2017). Sebagai tindak lanjut dari kesepakatan tahun 2005, pada tahun 2006, Kementerian Lingkungan Hidup mengembangkan program pendidikan lingkungan hidup pada jenjang pendidikan dasar dan menengah melalui program Adiwiyata (Desfandi, 2015).

Program Adiwiyata mengajarkan anak sejak dini untuk peduli dan berbudaya lingkungan serta berkarakter cinta lingkungan. Program Adiwiyata ini sangat baik dilaksanakan agar menciptakan masyarakat yang sejahtera serta peduli kepada lingkungannya. Hal ini juga sepadan dengan pendapat (Suryani dkk., 2019) bahwa program sekolah Adiwiyata memiliki peran strategis dalam peningkatan kepedulian lingkungan hidup yang sedang mengalami kemorosotan berat dewasa ini. Berdasarkan tujuan dan peran tersebut, kontribusi program Adiwiyata terhadap pembentukan karakter peduli lingkungan sangat mungkin terwujud. Khususnya, kondisi lingkungan sekolah yang baik bertujuan menjadikan tempat kegiatan pembelajaran yang kondusif dan meningkatkan penyadaran pada warga sekolah untuk turut bertanggung jawab dalam upayaupaya penyelamatan lingkungan hidup dan pembangunan berkelanjutan (Tompodung dkk., 2018).

Adiwiyata atau lingkungan hidup merupakan suatu ruang atau tempat yang ideal dan strategis, karena di dalamnya terjadi interaksi secara kondusif untuk mencapai kehidupan yang lebih baik (Widodo, 2017). Pelaksanaan program Adiwiyata diatur dalam Peraturan Menteri Lingkungan Hidup No. 05 Tahun 2013 untuk mencapai tujuan dari program Adiwiyata tersebut. Pada pelaksanaannya ditetapkan empat komponen program yang menjadi satu kesatuan utuh dalam mencapai sekolah Adiwiyata. Keempat komponen tersebut adalah (a) kebijakan berwawasan lingkungan, (b) pelaksanaan kurikulum berbasis lingkungan, (c) kegiatan lingkungan berbasis partisipatif, (d) pengelolaan sarana pendukung ramah lingkungan. Keempat komponen tersebut merupakan standar untuk mencapai tujuan dari program Adiwiyata sehingga sekolah harus mempersiapkan segala yang diperlukan untuk memenuhi standar tersebut (Azmi \& Elfayetti, 2017). Manfaat yang diperoleh program Adiwiyata antara lain menciptakan warga sekolah terutama peserta didik yang peduli dan berbudaya lingkungan, mendukung dan mewujudkan sumber daya manusia yang memiliki karakter nasional terhadap pembangunan ekonomi, sosial dan lingkungan dalam mencapai pembangunan berkelanjutan di suatu wilayah (Widodo, 2018). 
Berdasarkan hasil studi pendahuluan pada bulan Oktober 2019, SD Muhammadiyah Bantul Kota memulai program Adiwiyata pada tahun 2019 serta pada tahun tersebut SD Muhammadiyah Bantul Kota menjadi sekolah dasar swasta di Bantul yang telah mendapatkan penghargaan sekolah Adiwiyata terbaik tingkat Kabupaten Bantul pada tahun 2019 dengan menggabungkan Pendidikan Lingkungan Hidup (PLH) kedalam berbagai bidang antara lain kebijakan, kurikulum, kegiatan pembelajaran, dan sarana prasarana. Namun penerapan antara konsep ideal dengan praktik sering kali muncul masalah, seperti beberapa peserta didik belum maksimal dalam melaksanakan program. Hal ini dilihat dari kurangnya pemahaman peserta didik tentang cara menanam tanaman. Kebijakan yang dimiliki SD Muhammadiyah Bantul Kota tertulis dalam visi, misi dan tujuan sekolah yang mencerminkan nilai-nilai peduli lingkungan seperti membudayakan kegiatan menjaga pelestarian alam dengan 3R (Reduce, Reuse, Recycle), Wasti (Walau Sampah Tetap Indah), dan Germusa (Gerakan Memungut Sampah), dan membudayakan (tertera dalam tujuan sekolah), serta Rancangan Keuangan Anggaran Sekolah (RKAS) yang sudah dianggarkan untuk kegiatan peduli lingkungan sebesar $20 \%$ dari total anggaran sekolah, Kendala lainya adalah kurangnya partisipasi warga sekolah yang masih rendah, hal ini mengakibatkan beberapa program yang di rencanakan tidak berjalan dengan baik, seperti tanaman hidroponik yang sudah tidak ditanami tumbuhan.

Kurikulum berbasis lingkungan yang sudah terintegrasi dengan mata pelajaran wajib dan lokal yang dimiliki sekolah, serta pemahaman tentang PLH didapatkan peserta didik melalui proses pembelajaran sehari-hari. Walaupun pembelajaran tentang PLH sendiri sudah terintegrasi ke dalam mata pelajaran, namun belum dijadikan sebagai mata pelajaran khusus PLH. Kegiatan partisipatif SD Muhammadiyah Bantul Kota sudah bekerjasama dengan kemitraan berbagai pihak, seperti orang tua peserta didik, puskesmas, bank sampah "Gemah Ripah" dan sebagainya, serta sarana prasarana yang pendukung ramah lingkungan diantaranya greenhouse, daerah resapan air, dan kolam ikan. Dengan pencapaian tersebut, SD Muhammadiyah Bantul Kota berencana akan melanjutkan program Adiwiyata ke tingkat Provinsi pada tahun 2020. Namun SD Muhammadiyah Bantul Kota perlu adanya evaluasi untuk program Adiwiyata. Berdasarkan latar belakang ini peneliti tertarik untuk mengetahui mengenai program Adiwiyata yang ada di SD Muhammadiyah Bantul Kota. Penelitian ini bertujuan untuk mengevaluasi komponen-komponen program Adiwiyata di SD Muhammadiyah Bantul Kota dan mengetahui faktor pendukung serta penghambat dalam pelaksanaan Program Adiwiyata di SD Muhammadiyah Bantul Kota.

\section{METODE}

Penelitian ini menggunakan jenis penelitian evaluatif, dengan menggunakan model context, input, process, dan product (CIPP). Penelitian evaluasi bertujuan untuk mengetahui pencapaian 
tujuan program dengan langkah-langkah mengetahui keterlaksanaan kegiatan program, karena evaluator program ingin mengetahui bagian mana dari komponen dan sub-komponen program yang belum terlaksana dan apa sebabnya (Arikunto, 2014; Sukardi, 2011). Model evaluasi yang akan digunakan dalam penelitian ini adalah model CIPP. Model evaluasi CIPP ini meliputi evaluasi context, input, process, dan product dari pelaksanaan program yang akan diteliti yaitu Program Adiwiyata.

Evaluasi akan dilakukan mencakup empat komponen, meliputi (a) kebijakan berwawasan lingkungan, (b) pelaksanaan kurikulum berbasis lingkungan, (c) kegiatan lingkungan berbasis partisipatif, dan (d) pengelolaan sarana pendukung ramah lingkungan. Evaluasi dilakukan di SD Muhammadiyah Bantul Kota pada Tahun Ajaran 2019/2020. Data dikumpulkan melalui observasi, dokumentasi, dan wawancara dengan Kepala Sekolah, 2 Guru Kelas, 2 tim Adiwiyata, 2 karyawan, 3 peserta didik, komite, dan orang tua peserta didik. Data yang sudah terkumpul kemudian dianalisa melalui tahapan reduksi, penyajian, dan verifikasi data.

\section{HASIL DAN PEMBAHASAN}

\section{Aspek Context}

Context merupakan gambaran kegiatan yang ingin dicapai sekolah. Pada context ini, visi, misi dan tujuan sekolah termasuk didalamnya, karena visi, misi dan tujuan sekolah berisikan strategi yang dibuat sekolah untuk mencapai tujuannya, sehingga dapat menciptakan beberapa program yang akan dibentuk. Adapun visi, misi dan tujuan sekolah yang memuat upaya perlindungan hidup yaitu "bertaqwa, terdepan dalam prestasi, kreatif, dan berbudaya". Misi sekolah adalah membudayakan pola hidup bersih dan sehat dan membudayakan kegiatan menjaga pelestarian alam dengan 3 R, Wasti, dan Germusa. Tujuan sekolah adalah membudayakan peduli lingkungan dan terwujudnya sekolah berwawasan dan peduli lingkungan.

Analisis yang didapatkan dari data penelitian diatas bahwa visi, misi dan tujuan sekolah Adiwiyata sudah mencantumkan upaya perlindungan hidup dalam mewujudkan sekolah Adiwiyata. Visi, misi dan tujuan sekolah juga sudah diterapkan oleh warga sekolah dalam beberapa program seperti Germusa, pelestarian alam dan gerakan Wasti. Berdasarkan temuan tersebut, maka komponen conteks telah memenuhi kriteria pencapaian komponen program sekolah Adiwiyata (Yusuf dkk., 2020). Visi, misi, dan tujuan sekolah yang tertuang dalam KTSP memuat upaya perlindungan dan pengelolaan lingkungan hidup, mencegah terjadinya pencemaran dan kerusakan lingkungan hidup (Supriadi, 2020).

\section{Aspek Input}

Input menjelaskan penggunaan sumber-sumber yang dapat digunakan untuk mencapai tujuan dengan beberapa pencapaian sebagai berikut. 


\section{Anggaran Sekolah}

SD Muhammadiyah Bantul Kota sudah menganggarkan kegiatan upaya perlindungan dan pengelolaan pendidikan hidup sebesar $20 \%$ dilihat dari anggaran untuk pembelian sarana kebersihan, pelaksanaan kegiatan perlindungan lingkungan hidup seperti, pengadaan apotik hidup, greenhouse, tabulampot dan lain-lain. Sumber dana yang digunakan dalam pelaksanaan program Adiwiyata berasal dari BOS (Bantuan Operasional Sekolah) pusat dan Kabupaten. Berdasarkan hasil temuan tersebut, maka anggaran sekolah sudah memenuhi pencapaian komponen program sekolah Adiwiyata bahwa rencana kegiatan dan anggaran sekolah memuat upaya perlindungan dan pengelolaan lingkungan hidup (Maryani, 2016). Sekolah memiliki anggaran untuk upaya perlindungan dan pengelolaan lingkungan hidup sebesar 20\% dari total anggaran sekolah.

\section{Struktur Kurikulum}

Kurikulum yang digunakan SD Muhammadiyah Bantul Kota adalah Kurikulum 2013 sehingga dalam penerapan pendidikan lingkungan hidup diintegrasikan dengan mata pelajaran wajib. Kurikulum ini menjadi patokan guru serta warga sekolah dalam pelaksanaan proses pembelajaran baik itu mata pelajaran wajib maupun pendidikan lingkungan hidup. Menurut Mansur (2014), wujud sekolah dengan konsep lingkungan hidup yang nyata akan tercermin seperti sekolah memiliki kurikulum yang bermuatan wawasan lingkungan. Berdasarkan hasil temuan tersebut, maka struktur kurikulum sudah memenuhi pencapaian komponen program sekolah Adiwiyata bahwa struktur kurikulum memuat muatan lokal, pengembangan diri terkait kebijakan perlindungan dan pengelolaan lingkungan hidup (Pradini dkk., 2019). Pada kriteria struktur kurikulum memuat pelestarian fungsi lingkungan, mencegah terjadinya pencemaran, kerusakan lingkungan hidup pada komponen mata pelajaran wajib, muatan lokal, atau pengembangan diri.

\section{Kriteria Ketuntasan Minimal (KKM)}

SD Muhammadiyah Bantul Kota belum mempunyai KKM khusus dalam pendidikan lingkungan hidup, akan tetapi menjadi satu dengan KKM mata pelajaran wajib atau lokal. Sesuai dengan pedoman program sekolah Adiwiyata, yaitu adanya ketuntasan minimum belajar pada mata pelajaran wajib dan/atau muatan lokal yang terkait pendidikan lingkungan hidup. Berdasarkan hasil temuan tersebut, maka ketuntasan minimum belajar sudah memenuhi pencapaian komponen program sekolah Adiwiyata bahwa mata pelajaran wajib dan/atau muatan lokal yang terkait pendidikan lingkungan hidup dilengkapi dengan ketuntasan minimal belajar (Rokhmah, 2019). Ketuntasan minimal belajar pada mata pelajaran wajib dan/atau muatan lokal yang terkait dengan pelestarian fungsi lingkungan, mencegah terjadinya pencemaran, atau kerusakan lingkungan hidup.

\section{Penyusunan Rencana Pelaksanaan Pembelajaran (RPP)}


Pengintegrasian kurikulum berbasis lingkungan di SD Muhammadiyah Bantul Kota diwujudkan dengan guru mengembangkan RPP yang memuat pendidikan lingkungan hidup dengan diintegrasikan dengan mata pelajaran wajib. RPP sudah memuat pendidikan lingkungan hidup, yaitu dengan KD yang dikembangkan dan diintegrasikan dengan pendidikan lingkungan hidup, begitu juga kegiatan pembelajarannya sudah terdapat kegiatan yang memuat upaya perlindungan hidup. RPP merupakan perkiraan guru untuk melakukan tindakan yang akan dilakukan dalam kegiatan pembelajaran di kelas.

Pada penyusunan RPP guru mengembangkan indikator dan penilaian dari kompetensi dasar dalam materi pembelajaran yang akan diberikan kepada peserta didik (Wardani, 2020). Pada pengembangan indikator dan penilaian terkait pendidikan lingkungan hidup, guru melihat kompetensi dasar yang akan dipelajari kemudian diintegrasikan kedalam mata pelajaran wajib. Berdasarkan hasil temuan tersebut, maka penyusunan RPP sudah memenuhi pencapaian komponen program sekolah Adiwiyata dengan kriteria $70 \%$ tenaga pendidik menyusun rancangan pembelajaran yang terkait dengan perlindungan dan pengelolaan lingkungan hidup.

\section{Kesediaan Sarana dan Prasarana}

Sarana dan prasarana di SD Muhammadiyah Bantul Kota sudah tersedia untuk mengatasi permasalahan lingkungan hidup seperti terdapat air bersih, penyediaan sampah terpisah, drainase, ruang terbuka hijau dan toilet. Sarana dan prasarana juga ditambah dengan yang digunakan dalam proses pembelajaran peserta didik mengenai lingkungan hidup, seperti greenhouse, pengomposan, kolam ikan, pemanfaatan air wudhu untuk kolam ikan, dan hidroponik. Semua sarana dan prasarana tersebut sudah sesuai dengan pedoman pelaksanaan program sekolah Adiwiyata. Berdasarkan hasil temuan tersebut, maka sarana dan prasana penunjang pembelajaran serta upaya perlindungan hidup sudah memenuhi pencapaian komponen program sekolah Adiwiyata, yaitu menyediakan sarana dan prasarana untuk mendukung pembelajaran serta mengatasi permasalahan lingkungan hidup sekolah (Saputro \& Widodo, 2018). Pada kriteria tersedia enam sarana dan prasarana untuk mendukung pembelajaran dan mengatasi permasalahan lingkungan hidup.

\section{Kantin Sehat}

Kantin SD Muhaamdiyah Bantul Kota sudah menerapkan katin sehat serta ramah lingkungan sesuai dengan hasil observasi yang telah dilakukan, peserta didik sudah mengurangi penggunaan plastik sebagai wadah makanan dan menggantinya dengan mengunakan daun atau tempat makan yang dibawa peserta didik masing-masing. Pengelolaan makanan kantin SD Muhammadiyah Bantul kota langsung diawasi oleh pengurus kantin sekolah serta orang tua peserta didik, sehingga makanan dan minuman yang disediakan di kantin sudah mengandung gizi seimbang yang baik untuk peserta didik. Berdasarkan hasil temuan tersebut, maka pelayanan kantin sehat sudah memenuhi pencapaian komponen program sekolah Adiwiyata yaitu meningkatkan kualitas 
pelayanan kantin sehat dan ramah lingkungan (Sahani \& Lestari, 2019). Kantin melakukan tiga upaya dalam rangka meningkatkan kualitas pelayanan kantin sehat dan ramah lingkungan, meliputi (a) kantin tidak menjual makanan atau minuman yang mengandung bahan pengawet atau pengenyal, pewarna, perasa yang tidak sesuai dengan standar kesehatan; (b) tidak menjual makanan yang tercemar atau terkontaminasi, kadaluarsa; (c) tidak menjual makanan yang dikemas dengan kemasan tidak ramah lingkungan, seperti plastik, styrofoam, dan aluminium foil.

\section{Aspek Process}

\section{Proses Pembelajaran}

Kegiatan pembelajaran di SD Muhammadiyah Bantul Kota sudah mengajak peserta didik berperan aktif dalam pembelajaran dengan menggunakan metode student centered. Sesuai dengan kurikulum 2013, peserta didik diajak untuk lebih aktif dalam pembelajaran dan guru sebagai fasilitator peserta didik dalam proses pembelajaran. Pada pembelajaran juga mengaitakan dengan isu-isu lingkungan yang sedang marak diperbincangkan sehingga peserta didik mengetahui informasi terkait pencemaran lingkungan serta upaya perlindungan lingkungan hidup. Berdasarkan hasil temuan tersebut, maka proses pembelajaran di kelas maupun di luar kelas sudah memenuhi pencapaian komponen program sekolah Adiwiyata dengan kriteria $70 \%$ tenaga pendidik sudah menerapkan pembelajaran yang terkait dengan perlindungan dan pengelolaan lingkungan hidup (Pradini dkk., 2019).

\section{Keterlibatan Orang Tua Peserta Didik}

Orang tua peserta didik juga ikut andil dalam proses pembelajaran pendidikan lingkungan hidup, seperti mengundang orang tua peserta didik pada saat kegiatan yang berkaitan dengan lingkungan hidup yang ada di luar sekolah, atau dengan membantu peserta didik dalam proses pembelajaran yang ada di rumah. Orang tua juga membantu dengan menyumbangkan sarana dalam upaya perlindungan lingkungkan hidup seperti tempat pemilah sampah organik dan anorganik. Orang tua juga ikut serta dalam kegiatan yang dilakukan di sekolah maupun luar sekolah. Berdasarkan hasil temuan tersebut, maka keterlibatan orang tua sudah memenuhi pencapaian komponen program sekolah Adiwiyata yaitu tenaga pendidik mengikutsertakan orang tua peserta didik dan masyarakat dalam program pembelajaran lingkungan hidup (Desfandi, 2015). Dari kriteria, $50 \%$ orang tua peserta didik dan masyarakat mengikuti kegiatan pembelajaran yang terkait dengan perlindungan dan pengelolaan lingkungan hidup.

\section{Pemeliharaan Sarana dan Prasarana Sekolah}

SD Muhammadiyah Bantul Kota sudah mengadakan beberapa kegiatan yang dilakukan dalam pemeliharaan gedung serta lingkungan seperti Germusa (gerakan memungut sampah) kemudian Jumat bersih, kegiatan piket kelas yang dilaksanakan setiap hari oleh peserta didik dan perawatan 
tanaman. Pelaksanaannya dilakukan oleh seluruh warga sekolah dari kepala sekolah guru, karyawan serta peserta didik sehingga seluruh warga sekolah memiliki tanggung jawab dalam pemeliharaan gedung dan lingkungan sekolah.

SD Muhammadiyah Bantul Kota sudat memiliki jendela di setiap kelas, tetapi karena menggunakan AC, sehingga tidak ada cahaya matahari yang masuk kedalam kelas. Halaman sekolah sudah dipenuhi pohon sebagai peneduh serta penghijauan di sekolah, serta sekolah sudah menggunakan paving block di halaman serta area sekolah lainnya. Pemeliharaan tanaman yang dilakukan oleh warga sekolah masih kurang, karena tanaman yang terdapat pada hidroponik sudah tidak tumbuh lagi.

Berdasarkan hasil temuan tersebut, pemeliharaan sarana dan prasarana di SD Muhammadiyah Bantul Kota sudah memenuhi pencapaian komponen program sekolah Adiwiyata. Pencapaian tersebut termuat dalam buku Panduan Adiwiyata (2012:15), yaitu memelihara dan merawat gedung dan lingkungan sekolah oleh warga sekolah. Dari kriteria, 80\% warga sekolah terlibat dalam pemeliharaan gedung dan lingkungan sekolah dengan program-program yang sudah dibuat.

Pemeliharaan sarana dan prasarana sekolah ramah lingkungan sudah mendekati pencapaian komponen program sekolah Adiwiyata dengan kriteria berikut. Terpeliharanya tiga sarana dan prasarana yang ramah lingkungan sesuai fungsinya, antara lain (a) ruang memiliki pengaturan cahaya dan ventilasi udara secara alami; (b) pemeliharaan dan pengaturan pohon peneduh dan penghijauan; (c) menggunakan paving block meskipun ruangan yang menggunakan AC sehingga tidak mendapatkan udara secara alami, serta pencahayaan yang kurang karena ruang yang tertutup.

\section{Memanfaatkan Lahan dan Fasilitas Sekolah.}

SD Muhammadiyah Bantul Kota sudah memanfaatkan beberapa lahan seperti adanya kolam ikan, greenhouse, penanaman hidroponik, apotek hidup yang ditanami berbagai tanaman obat maupun sayur, pembuatan lubang biopori untuk menampung air wudhu, serta lahan untuk pengomposan. Berdasarkan hasil temuan tersebut, pemanfaatan lahan di SD Muhammadiyah Bantul Kota sudah memenuhi pencapaian komponen program sekolah Adiwiyata yaitu memelihara dan merawat gedung dan lingkungan sekolah oleh warga sekolah. Dari kriteria, 80\% warga sekolah terlibat sekolah memanfaatkan lahan dan fasilitas sekolah sesuai kaidah-kaidah PPLH.

\section{Kegiatan Aksi Lingkungan di Luar Sekolah}

SD Muhammadiyah Bantul Kota sudah mengikuti kegiatan lingkungan hidup di luar sekolah, yaitu dengan mewakilkan beberapa peserta didik untuk mengikutinya, kegiatan tersebut antara lain, mengikuti seminar bertema lingkungan hidup, field trip penanaman seribu pohon mangrove serta kegiatan pelatihan daur ulang sampah. Kegiatan yang diikuti oleh guru dan peserta didik SD Muhammadiyah Bantul Kota memenuhi tiga kegiatan dari enam kegiatan yang sesuai dengan 
kriteria yang telah ditentukan. Berdasarkan hasil temuan tersebut, kegiatan aksi lingkungan di luar sekolah belum sepenuhnya memenuhi pencapaian komponen program sekolah Adiwiyata, yaitu mengikuti kegiatan aksi lingkungan hidup yang dilakukan oleh pihak luar (Haris, 2018). Idealnya, kegiatan yang dilakukan antara lain tenaga pendidik dan peserta didik mengikuti enam kegiatan aksi lingkungan hidup yang dilakukan oleh pihak luar (Desfandi, 2015).

\section{Menjalin Kerjsama}

Pelaksanaan program sekolah Adiwiyata di SD Muhammadiyah Bantul Kota juga mendapatkan dukungan dari berbagai instansi baik dalam hal lingkungan dan kesehatan, seperti Dinas Lingkungan Hidup (DLH), Pembina Kesehatan Umum (PKU), SDN 1 Bantul, dan UMY. Dalam mengoptimalkan kerjasama dengan pihak lain, sekolah juga mengundang beberapa instansi sebagai narasumber dalam kegiatan lingkungan hidup yang diadakan sekolah. Kegiatan tersebut dilaksanakan dengan mengundang Dinas Lingkungan Hidup (DLH) Kabupaten Bantul untuk mensosialisasikan hemat energi, baik listrik dan air, kemudian mengundang dari pengrajin bahan sampah plastik yang mengajarkan pemanfaatan bahan plastik sebagai barang yang berguna. Berdasarkan hasil temuan tersebut, dukungan dari pihak lain di SD Muhammadiyah Bantul Kota sudah memenuhi pencapaian komponen program sekolah Adiwiyata dengan kriteria tiga mitra yang dimanfaatkan sebagai narasumber serta mendukung dalam bentuk materi untuk kegiatan yang terkait dengan pendidikan lingkungan hidup (Supriadi, 2020).

\section{Peran Komite Sekolah}

Selain mendapatkan dukungan dari pihak luar seperti Dinas Lingkungan Hidup (DLH), Pembina Kesehatan Umum (PKU), SDN 1 Bantul, dan UMY untuk meningkatkan pendidikan lingkungan hidup, dukungan tersebut juga tidak lepas dari peran dan dukungan dari komite sekolah. Komite sekolah membantu dalam pelaksanaan kegiatan program Adiwiyata sekolah dengan berpartisipasi dalam kegiatannya. Berdasarkan hasil temuan tersebut, peran komite sekolah belum memenuhi pencapaian komponen program sekolah Adiwiyata dengan kriteria tiga kemitraan yang difasilitasi oleh komite sekolah untuk kegiatan aksi bersama terkait dengan pembelajaran lingkungan hidup dan upaya perlindungan dan pengelolaan lingkungan hidup (Maryani, 2016).

\section{Penggunaan Air, Listrik dan Alat Tulis Kantor (ATK)}

Dari data yang didapatkan bahwa dalam penggunaan listrik, air dan ATK sudah dimanfaatkan dengan sebaik mungkin. Hal ini dilaksanakan dengan memberikan himbauan berupa poster hemat energi yang dipasang didinding kelas atau kamar mandi. Penerapan lainnya yaitu mematikan lampu dan kipas angin apabila sudah tidak digunakan, begitupun dengan penggunaan air secukupnya. Tetapi masih terdapat peserta didik yang menggunakan air secara berlebihan. Dari 
data tersebut, SD Muhammadiyah Bantul Kota sudah melaksanakan sesuai dengan pencapaian komponen program sekolah Adiwiyata, yaitu memanfaatkan listrik, air dan alat tulis kantor secara efisien. Dari kriteria, 20\% efisiensi pemanfaatan listrik, air dan alat tulis kantor.

\section{Aspek Product}

\section{Hasil Karya}

Peserta didik tidak hanyak di berikan materi terkait upaya perlindungan lingkungan hidup, tetapi juga melakukan praktek, seperti membuat karya puisi, menggambar dengan tema lingkungan dan juga memanfaatkan barang bekas dari botol menjadi pot tanaman, plastik bekas bahan makanan dijadikan keranjang dan juga menjadi baju cantik. Tenaga pendidik sudah membuat beberapa karya yang berkaitan dengan lingkungan hidup, seperti membuat baju dari barang bekas, serta membuat meja dari ban bekas. Dari hasil karya peserta didik dan tenaga pendidik juga di publikasikan dalam bentuk media online seperti mengunggah di youtube atau facebook, kemudian juga dipublikasikan dalam media offline seperti mading sekolah, dan majalah sekolah. Dari data tersebut peserta didik SD Muhammadiyah Bantul Kota sudah membuat beberapa karya sesuai dengan pencapaian komponen program sekolah Adiwiyata, yaitu peserta didik menghasilkan karya nyata yang berkaitan dengan pendidikan lingkungan hidup, dan mengomunikasikannya dengan berbagai cara dan media (Rokhmah, 2019). Dari kriteria, 50\% peserta didik menghasilkan karya nyata yang berkaitan dengan pendidikan lingkungan hidup, seperti puisi, artikel, gambar, seni tari, produk daur ulang, dan mengomunikasikannya dengan berbagai cara dan media, misalnya majalah dinding, buletin sekolah, pameran, website, radio, televisi, dan lainnya.

\section{Kegiatan Peserta Didik}

Guru mengajarkan pada peserta didik mengenai cara menjaga lingkungan seperti membuang sampah pada tempatnya, melaksanakan piket kelas, dan lainnya. Ajaran-ajaran dari guru tersebut menjadi kebiasaan dalam menerapkan pengetahuan yang diperoleh, tetapi masih terdapat peserta didik yang belum melaksanakannya. Dari data, peserta didik sudah mulai mengimplementasikannya dalam kehidupan sehari-hari sesuai dengan pencapaian komponen program sekolah Adiwiyata, yaitu peserta didik menerapkan pengetahuan lingkungan hidup yang diperoleh untuk memecahkan masalah lingkungan hidup dalam kehidupan sehari-hari (Saputro \& Widodo, 2018). Peserta didik menerapkan pengetahuan lingkungan hidup yang diperoleh untuk memecahkan masalah lingkungan hidup dalam kehidupan sehari-hari (Gunawan, 2004).

\section{Kreativitas Warga Sekolah}

Warga sekolah juga membuat beberapa kreativitas atau karya yang bertemakan upaya perlindungan hidup. Adapun hasil karya dari warga sekolah seperti membuat greenhouse, pemanfaatan air wudhu untuk air kolam ikan, ada Wasti berupa pakaian yang berbahan dari koran 
dan plastik bungkus makanan. Warga sekolah SD Muhammadiyah Bantul Kota juga memberikan dukungan dan membina sekolah lain maupun masyarakat sekitar, bentuk dukungan yang diberikan yaitu menjadi narasumber di karang taruna Dusun Tamanan Banguntapan Bantul kemudian mengisi di salah satu UKM mahasiswa UMY. Berdasarkan hasil temuan tersebut, peran warga sekolah sudah memenuhi pencapaian komponen program sekolah Adiwiyata dengan kriteria membuat lima kegiatan kreativitas dan inovasi dalam upaya PPLH dan tiga kali menjadi narasumber dalam rangka pembelajaran lingkungan hidup (Yusuf dkk., 2020).

\section{Faktor Pendukung Program Adiwiyata}

Faktor pendukung dari program sekolah Adiwiyata di SD Muhammadiyah Bantul Kota adalah guru yang membantu menerapkan kegiatan, sarana prasarana yang disediakan sekolah sehingga dapat terlaksana denga baik serta dukungan dari pihak lain yang dapat memunculkan semangat warga sekolah sehingga proses pelaksanaan program Adiwiyata dapat berjalan dengan baik. Hal ini sesuai dengan pendapat (Permana \& Ulfatin, 2018) bahwa dukungan sosial dapat dianggap sebagai sesuatu keadaan yang bermanfaat bagi individu yang diperoleh dari orang lain yang dapat dipercaya. Dari keadaan tersebut individu akan mengetahui bahwa orang lain memperhatikan, menghargai, dan mencintainya. Hal ini akan memberikan semangat dalam melaksanakan kegiatan yang lain.

\section{Faktor Penghambat Program Adiwiyata}

Faktor penghambat dari program sekolah Adiwiyata di SD Muhammadiyah Bantul Kota adalah anggaran dana yang masih kurang untuk pelaksanaan kegiatan, kurangnya kepekaan warga sekolah terhadap lingkungan sekitar, serta kurangnya pengetahuan warga sekolah tentang lingkungan hidup. Menurut Nurhayati dkk. (2020) kepekaan sosial atau social sensitivity dapat diartikan sebagai tindakan seseorang untuk bereaksi secara cepat dan tepat terhadap objek atau situasi sosial yang ada di lingkungan sekitar. Kepekaan sosial perlu di kembangkan lebih lanjut untuk mengurangi sifat egosentrisme dan mengembangkan rasa empati terhadap orang lain yang ada di sekitar.

\section{SIMPULAN DAN SARAN}

\section{Simpulan}

Evaluasi Program Adiwiyata menunjukkan bahwa dari aspek context, SD Muhammadiyah Bantul Kota telah memiliki visi, misi dan tujuan sekolah untuk mencapai sekolah Adiwiyata. Pada aspek input, SD Muhammadiyah Bantul Kota pada tahun 2018 dan 2019 telah mengalokasikan anggaran sebesar $20 \%$ untuk kegiatan pendidikan lingkungan hidup, kurikulum yang mengintegrasikan pendidikan lingkungan hidup, ketuntasan minimal belajar pada pendidikan lingkungan hidup, pembuatan RPP terkait pembelajaran lingkungan hidup, tersedianya sarana 
prasarana yang mendukung. Pada aspek process, sekolah telah melibatkan guru, peserta didik, wali murid, dan warga sekolah lainnya dalam kegiatan lingkungan hidup serta berkerjasama dengan instansi lain dalam pelaksanaan kegiatan program Adiwiyata. Pada aspek product, terdapat karya dari guru dan peserta didik terkait pendidikan lingkungan hidup dan juga telah diduplikasikan. Faktor pendukung dalam pelaksanaan Program Adiwiyata di SD Muhammadiyah Bantul Kota antara lain tersedianya SDM dan sarana prasarana yang cukup memadai. Faktor penghambat pelaksanaanya antara lain kurangnya motivasi peserta didik untuk menjaga lingkungan.

\section{Saran}

Dari hasil penelitian ini disarankan kepada sekolah mengadakan mata pelajaran khusus mengenai pendidikan lingkungan hidup agar peserta didik dapat mengetahui secara mendetail bagaimana cara mengatasi permasalahan lingkungan hidup serta upaya perlingdungan lingkungan hidup dan dapat mengimplementasikannya dengan lebih baik. Selain itu, warga sekolah sebaiknya melakukan kegiatan pemeliharaan lingkungan hidup secara rutin dan mengikuti kegiatan yang diadakan di luar sekolah agar bertambah ilmu mengenai pendidikan lingkungan hidup untuk diaplikasikan di sekolah.

\section{DAFTAR RUJUKAN}

Arikunto, S. (2014). Evaluasi Program Pendidikan Program Pedoman Teoritis Bagi Mahasiswa dan Praktisi Pendidikan. Bumi Aksara.

Azmi, F., \& Elfayetti, E. (2017). Analisis Sikap Peduli Lingkungan Siswa Melalui Program Adiwiyata di SMA Negeri 1 Medan. Jurnal Geografi, 9(2), 125. https://doi.org/10.24114/jg.v9i2.6901

Desfandi, M. (2015). Mewujudkan Masyarakat Berkarakter Peduli Lingkungan Melalui Program Adiwiyata. Sosio Didaktika: Social Science Education Journal, 2(1), 31-37. https://doi.org/10.15408/sd.v2i1.1661

Diyan Nurvika Kusuma Wardani. (2020). Analisis Implementasi Program Adiwiyata dalam Membangun Karakter Peduli Lingkungan. Southeast Asian Journal of Islamic Education Management, 1(1), 60-73. https://doi.org/10.21154/sajiem.v1i1.6

Gunawan, I. (2004). Metode Penelitian Kualitatif: Teori dan Praktik. PT Bumi Aksara.

Haris, E. (2018). Sekolah Adiwiyata Panduan Implementasi Adiwiyata Mandiri di Sekolah. Jakarta: Esensi, Erlangga Grup. Esensi Erlangga.

Mansur, M. (2014). Pendidikan Karakter Menjawab Tantangan Krisis Multidimensional. Bumi Aksara.

Maryani, I. (2016). Evaluasi Pelaksanaan Program Sekolah Adiwiyata Ditinjau Dari Aspek Kegiatan Partisipatif di SDN Ungaran I Yogyakarta. Jurnal Pemikiran Dan Pengembangan Sekolah Dasar (JP2SD), 1(3), 170. https://doi.org/10.22219/jp2sd.v1i3.2723

Nurhayati, N., Pitoweas, B., Putri, D. S., \& Yanzi, H. (2020). Analisis Kepekaan Sosial Generasi (Z) Di Era Digital Dalam Menyikapi Masalah Sosial. Bhineka Tunggal Ika: Kajian Teori Dan Praktik Pendidikan PKn, 7(1), 17-23. https://doi.org/10.36706/jbti.v7i1.11415 
Permana, B. I., \& Ulfatin, N. (2018). Budaya Sekolah Berwawasan Lingkungan pada Sekolah Adiwiyata Mandiri. Ilmu Pendidikan: Jurnal Kajian Teori Dan Praktik Kependidikan, 3(1), 11-21. https://doi.org/10.17977/um027v3i12018p011

Pradini, I. K., Sudjanto, B., \& Nurjannah, N. (2019). Implementasi Program Sekolah Adiwiyata Dalam Peningkatan Mutu Pendidikan di SDN Tanah Tinggi 3 Kota Tangerang. Jurnal Green Growth dan Manajemen Lingkungan, 7(2), 122-132. https://doi.org/10.21009/jgg.072.03

Rokhmah, U. N. (2019). Pelaksanaan Program Adiwiyata Sebagai Upaya Pembentukan Karakter Peduli Lingkungan Siswa di Madrasah Ibtidaiyah. Al Qalam: Jurnal Ilmiah Keagamaan dan Kemasyarakatan, 67. https://doi.org/10.35931/aq.v0i0.133

Sahani, W., \& Lestari, G. D. (2019). Hubungan Pengetahuan Pengelola Kantin Dengan Penerapan Program Adiwiyata Kantin Sehat SD di Kota Makassar. Sulolipu: Media Komunikasi Sivitas Akademika Dan Masyarakat, 17(1), 79. https://doi.org/10.32382/sulolipu.v18i1.727

Saputro, H. B., \& Widodo, H. (2018). Making Students Carefully Catering Environment Through Adiwiyata Program. Proceedings of the 3rd Annual International Seminar on Transformative Education and Educational Leadership (AISTEEL 2018), Medan, Indonesia. https://doi.org/10.2991/aisteel-18.2018.152

Sukardi. (2011). Evaluasi Pendidikan Prinsip \& Operasionalnya. Bumi Aksara.

Supriadi, S. (2020). Implementasi Metode Demonstrasi Untuk Meningkatkan Pengetahuan Guru Terhadap Sekolah Adiwiyata. Jurnal Pajar (Pendidikan dan Pengajaran), 4(1). https://doi.org/10.33578/pjr.v4i1.7928

Suryani, A., Soedarso, S., Saifulloh, M., Muhibbin, Z., Wahyuddin, W., Hanoraga, T., Nurif, M., Trisyanti, U., Rahadiantino, L., \& Rahmawati, D. (2019). Education for Environmental Sustainability: A Green School Development. IPTEK Journal of Proceedings Series, O(6), 65. https://doi.org/10.12962/j23546026.y2019i6.6347

Tim Penulis. (2017). Buku Panduan Puncak Acara Peringatan Hari Lingkungan Hidup 2017 dan Landmark Hutan Indonesia. Kementerian Lingkungan Hidup Dan Kehutanan.

Tompodung, T. C. G., Rushayati, S. B., \& Aidi, M. N. (2018). Efektivitas Program Adiwiyata Terhadap Perilaku Ramah Lingkungan Warga Sekolah di Kota Depok. Jurnal Pengelolaan Sumberdaya Alam dan Lingkungan (Journal of Natural Resources and Environmental Management), 8(2), 170-177. https://doi.org/10.29244/jpsl.8.2.170-177

Widodo, Hendro. 2017. Budaya Sekolah Adiwiyata Studi Kasus di SD Muhammadiyah Bodon Bantul Yogyakarta. Tajdidukasi. VII (1): 1-18.

Widodo, Hendro. 2018. Making Students Carefully Catering Environment Through Adiwiyata Program. Advances in Social Science, Education and Humanities Research. 200 : 699-703.

Yusuf, R., Sanusi, S., Maimun, M., Fajri, I., \& Putra, I. (2020). Hubungan Antara Kewarganegaraan Lingkungan Terhadap Perilaku Lingkungan Siswa di Sekolah Adiwiyata. Jurnal Pendidikan Kewarganegaraan, 10(1), 1. https://doi.org/10.20527 kewarganegaraan. v10i1.8215 